\title{
Assessment of Oyster Mushrooms Found on Polluted Soil for Consumption
}

\author{
Olutayo M. Adedokun \\ Department of Crop and Soil Science, University of Port Harcourt, Port Harcourt, Nigeria \\ Email: olutayo.adedokun@gmail.com
}

Received 4 February 2015; accepted 4 May 2015; published 6 May 2015

Copyright (C) 2015 by author and Scientific Research Publishing Inc.

This work is licensed under the Creative Commons Attribution International License (CC BY). http://creativecommons.org/licenses/by/4.0/

(c) (7) Open Access

\begin{abstract}
Aim: A simulation experiment was carried out in which oyster mushrooms (Pleurotus pulmonarius) was grown on used engine oil. This study was designed to evaluate the remnant hydrocarbon in the sporophore (fruiting body) of Pleurotus pulmonarius and to assess its suitability for human consumption. Method: The mycelia of the mushroom were used to inoculate Spent Engine Oil (SEO, $10 \%(\mathrm{v} / \mathrm{w})$ ) polluted soil. After four weeks of incubation, fruiting bodies growing on the polluted soil were analyzed for remnant hydrocarbon profile. Results: Results showed that total Polycyclic Aromatic Hydrocarbon (PAH) was $10 \mathrm{mg} / \mathrm{kg}$ and Aliphatic Hydrocarbon (AH) was $23 \mathrm{mg} / \mathrm{kg}$. The hydrocarbon profile indicated some $\mathrm{AH}$ and $\mathrm{PAH}$ were within the non-cancer reference dose while a few others were above the non-cancer daily reference dose range. Conclusion: The detection of some hydrocarbon profile above the non-cancer daily reference dose makes the test-mushroom used for bioremediation not safe for human consumption. This underscores the need for caution in consuming mushrooms found in oil polluted environment.
\end{abstract}

\section{Keywords}

Oyster Mushroom, Hydrocarbon Profile, Used Engine Oil, Consumption, Pollution

\section{Introduction}

Oil pollution is a global challenge. It adversely affects fertile land and marine ecosystems [1] [2] and ultimately the health of people around the contaminated site [3]. Pollutants are introduced into the ecosystem as a result of human activities. Used oil is disposed indiscriminately after engine services in some countries both by mechanics and individuals. These pollutants which seep into water bodies and farmland are hazardous to living things. [4] reported that large amount of hydrocarbons were found in used oil including the highly toxic Polycyclic Aromatic Hydrocarbon (PAH). The physical, chemical and microbiological contents of soil were changed and negatively affected where these were found [5]. Consequently, these polluted sites require some remedial meas- 
ures for clean-up. One of such measures is bioremediation. Several studies have been conducted on the use of edible fungi in bioremediation. Among these are Pleurotus osteatus [6] [7]; Pleurotus pulmonarius, Pleurotus squarrosulus, Pleurotus tuber regium [8] [9]; Pleurotus tuber-regium, Lentinus subnudus [10] and Pleurotus eryngii [11].

[8] reported the use of mushrooms in bioaugmentation in a polluted site where cowpea was planted. However, reports are limited on use of sporophores after bioremediation processes especially in relation to possible human consumption. Is oyster mushroom used for bioremediation fit for human consumption? Is it also safe to pick mushrooms from oil polluted soil if found? If the mushroom is assessed safe for consumption, it could both supplement protein intake and income of people where oil pollution is a great challenge to food security. This study was designed to evaluate the remnant hydrocarbon in the fruiting body of Pleurotus pulmonarius and to assess its safety for human consumption.

\section{Materials and Method}

A simulation experiment was carried out in which samples were treated according to the method of [12] modified as follows: Briefly, one kilogram of sandy loam soil was weighed into transparent polythene bags. The samples were treated with $10 \%(\mathrm{v} / \mathrm{w})$ Spent Engine Oil. 10\% (w/w) waste cotton were added to the polluted samples (as substrate for the mushroom) and thoroughly mixed with it. The samples were sterilized in an autoclave at $121^{\circ} \mathrm{C}$ for 15 minutes and inoculated with $10 \%$ Pleurotus pulmonarius. Control experiment was not treated with SEO. All the treatments were incubated at room temperature $\left(28^{\circ} \mathrm{C} \pm 2^{\circ} \mathrm{C}\right)$ for four weeks.

\subsection{Determination of $\mathrm{AH}$ and $\mathrm{PAH}$}

Mushroom samples harvested from the polluted soil were analyzed for aliphatic and aromatic hydrocarbons according to [13] using Agilent 6890 GC (Flame Ionization Detector). Hydrocarbon profile was tested for by the following steps.

\subsection{Sample Preparation and Extraction (Sonication Water Bath Method)}

Mushroom sample $2.0 \pm 0.1 \mathrm{~g}$ was weighed into a clean extraction bottle and dried with anhydrous sodium sulphate. $1 \mathrm{ml}$ of $60 \mu \mathrm{g} / \mathrm{ml}$ o-Terphenyl was added as Poly aromatic Hydrocarbon standard. $40 \mathrm{~mL}$ of extraction solvent was added and the mixture placed in shaking water bath for 5 hours. The extract was allowed to settle for 1 hour and sample carefully filtered through funnel fitted with cotton wool and sodium sulphate into a clean amber coloured extraction bottles washed with methylene chloride. Residue was washed with $20 \mathrm{~mL}$ of extraction solvent and filtered through the funnel. The sample extract was concentrated by diluting $2 \mathrm{~mL}$ sample extract to $10 \mathrm{ml}$ with methylene chloride. Sample was further concentrated to $1 \mathrm{~mL}$ using a rotary evaporator. The concentrated extract was cleaned up, separated and analyzed for PAH. The above step was repeated for Aliphatic Hydrocarbon extraction using 1-Chlorooctadecane as standard.

\section{Results}

Fruiting bodies of $P$. pulmonarius were found growing on the polluted soil after four weeks. The total hydrocarbon contents of mushrooms harvested from the soil polluted with SEO are presented in Figure 1 and Figure 2. The total remnant Aliphatic Hydrocarbon (AH) was $23 \mathrm{mg} / \mathrm{kg}$. The Aliphatic Hydrocabon profile indicated nOctadecane $(0.34 \mathrm{mg} / \mathrm{kg})$, n-Phytane $(0.30 \mathrm{mg} / \mathrm{kg})$, n-Nonadecane $(0.28 \mathrm{mg} / \mathrm{kg}), \mathrm{n}$-Eicosane $(0.74 \mathrm{mg} / \mathrm{kg}), \mathrm{n}$ Heneicosane (1.47 mg/kg), n-Docosane (1.76 mg/kg), n-Heptacosane (1.98 mg/kg), n-Nonacosane (1.53 mg/kg), n-Tricontane (1.57 mg/kg), n-Hentriacontane (1.30 mg/kg), n-Octacosane $(2.01 \mathrm{mg} / \mathrm{kg}), \mathrm{n}$-Hexacosane (2.19 $\mathrm{mg} / \mathrm{kg})$, n-Tricosane $(2.35 \mathrm{mg} / \mathrm{kg})$, n-Pentacosane $(2.36 \mathrm{mg} / \mathrm{kg})$ and n-Tetracosane $(2.72 \mathrm{mg} / \mathrm{kg})$ ranged between 0.28 and $2.72 \mathrm{mg} / \mathrm{kg}$ (Figure 1). Similarly, total remnant PAH was $10 \mathrm{mg} / \mathrm{kg}$. From the results of the PAH profile Naphthalene, Acenaphthene, Fluorene, Anthracene, Dibenzo (a, h) anthracene, Benzo (g, h, i) perylene and Indeno (1, 2, 3-d) pyrene were not detected (Table 1). However, Fluoranthene $(0.06 \mathrm{mg} / \mathrm{kg})$, Acenapthylene $(0.22 \mathrm{mg} / \mathrm{kg})$, 2-Methylnaphtalene $(0.26 \mathrm{mg} / \mathrm{kg})$, Phenanthrene $(0.32 \mathrm{mg} / \mathrm{kg})$, Benzo $(\mathrm{k})$ fluoranthene $(0.37$ $\mathrm{mg} / \mathrm{kg}$ ), Benzo (a) anthracene (0.42 mg/kg), Benzo (b) fluoranthene (0.46 mg/kg), Benzo (a) pyrene (0.54 mg/kg) and chrysene $(5.30 \mathrm{mg} / \mathrm{kg})$ indicated a range between 0.42 and $5.30 \mathrm{mg} / \mathrm{kg}$ (Table 2). 


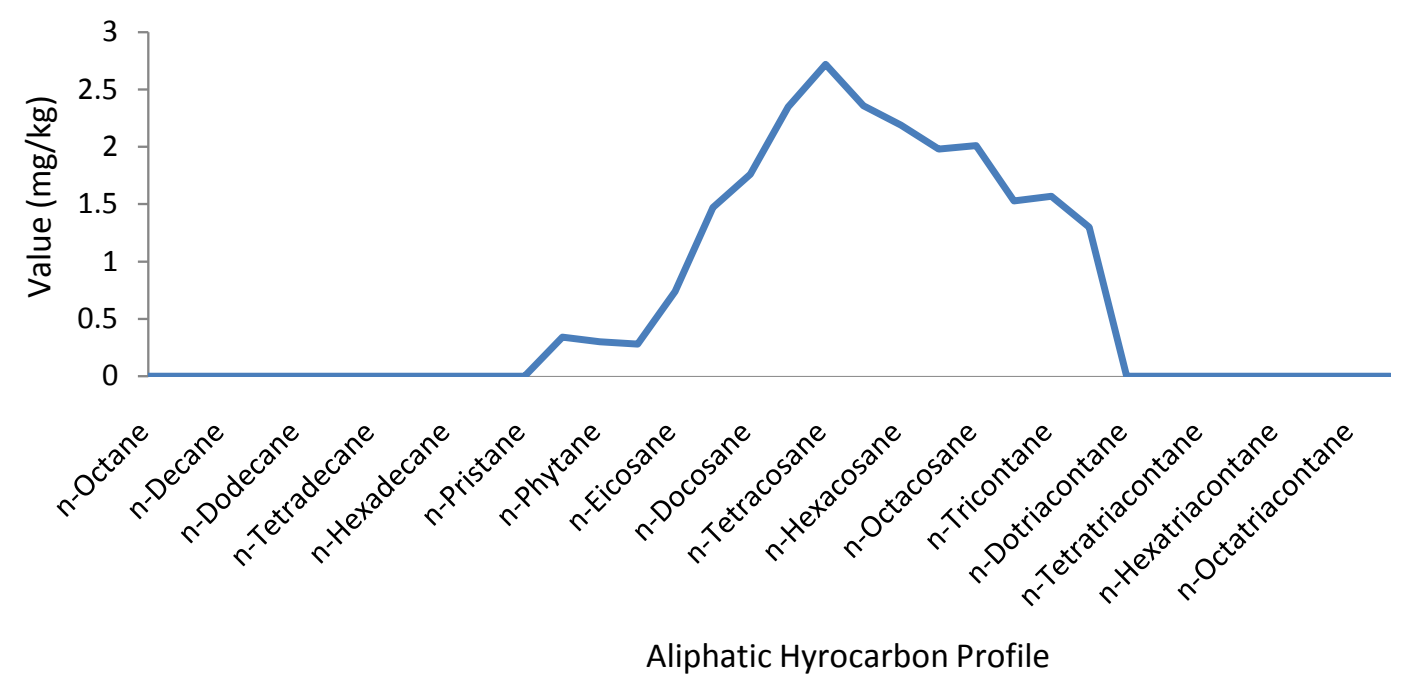

Figure 1. Aliphatic hydrocarbon contents of oyster mushroom harvested on polluted soil.

Table 1. Hydrocarbons fractions of oyster mushroom versus reference.

\begin{tabular}{ccc}
\hline Petroleum Hydrocarbon Fraction & Non-Cancer Reference Dose $\mathrm{mg} / \mathrm{kg} / \mathrm{day}(\mathrm{ODEQ} 2003)$ & Mushroom $(\mathrm{SEO})(\mathrm{mg} / \mathrm{kg})$ \\
\hline Aliphatic $>$ C8 - C10 & 0.3 & Not detected \\
Aliphatic > C10 - C12 & 0.3 & Not detected \\
Aliphatic > C12 - C16 & 0.3 & $0.28-1.98$ \\
Aliphatic > C16 - C21 & 2 & $0.74-2.72$ \\
Aliphatic > C21 - C34 & 2 & Not detected \\
Aromatic > C8 - C10 & 0.06 & $0.22-0.26$ \\
Aromatic > C10 - C12 & 0.06 & $0.06-0.22$ \\
Aromatic > C12 - C16 & 0.06 & Not detected \\
Aromatic > C16 - C21 & 0.03 & $0.26-0.54$ \\
Aromatic > C21 - C35 & 0.03 & Not detected \\
n-Hexane & 0.05 & Not detected \\
Benzene & 0.008 & Not detected \\
\hline
\end{tabular}

Table 2. Hydrocarbon profile above the non-cancer reference range.

\begin{tabular}{|c|c|c|c|c|c|}
\hline Aliphatic profile & Value (mg/kg) & Non-Cancer Range (mg/kg) & Polycyclic Aromatic Profile & Value (mg/kg) & Non-Cancer Range (mg/kg) \\
\hline n-Octacosane & 2.01 & $0.3-2.0$ & Acenapthylene & 0.22 & $0.00-0.06$ \\
\hline n-Hexacosane & 2.19 & & 2-Methylnaphtalene & 0.26 & \\
\hline n-Tricosane & 2.35 & & Phnanthrene & 0.32 & \\
\hline n-Pentacosane & 2.36 & & Benzo (k) fluoranthene & 0.37 & \\
\hline \multirow[t]{4}{*}{ n-Tetracosane } & 2.72 & & Benzo (a) anthrancene & 0.42 & \\
\hline & & & Benzo (b) fluoranthene & 0.46 & \\
\hline & & & Benzo (a) pyrene & 0.54 & \\
\hline & & & Chrysene & 5.30 & \\
\hline
\end{tabular}



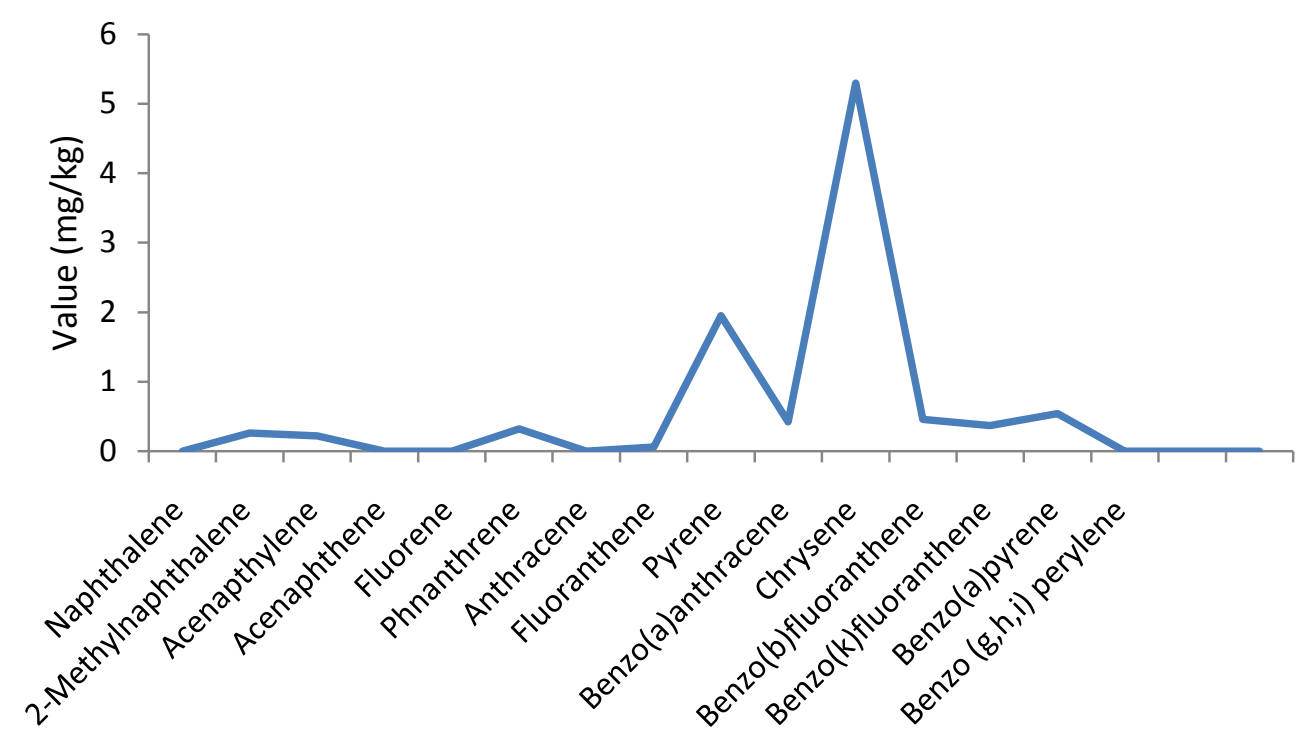

Polycyclic Hydrocarbon Profile

Figure 2. Polycyclic Aromatic Hydrocarbon contents of oyster mushrooms harvested on polluted soil.

\section{Discussion}

The fruiting bodies of $P$. pulmonarius growing on polluted soil suggested that the fungus, with the aid of hydrolytic enzymes, produced, degraded the SEO thereby proliferating its own cells. [14] reported that the degradation ability of mushrooms was dependent on the enzymes they produced. Other researchers who have reported the ability of mushrooms to clean up toxic substances include [15]-[17]. The AH profile ranged from 0.28 - 1.98 $\mathrm{mg} / \mathrm{kg}$ and the PAH profile ranged from $0.00-0.06 \mathrm{mg} / \mathrm{kg}$ were within the non-cancer dose while those with higher values were outside the non-cancer reference dose [18].

Similar reference doses were recorded by Canadian Council of the Ministers of the Environment (CCME) [19] as the soil quality guideline for portable water. According to CCME document, PAHs are a group of complex hydrocarbons made up of two or more benzene rings fused in a linear, angular or cluster arrangement and some are carcinogenic while others are not. With the presence of remnant hydrocarbons in the analyzed mushrooms, they may not be recommended for human consumption. However, possibilities of consuming mushrooms used for bioremediation may not be impossible as reported by [15].

\section{Conclusion}

The detection of some hydrocarbon profiles above the non-cancer daily reference dose makes the tested mushroom used for bioremediation not safe for human consumption. This underscores the need for caution in consuming mushrooms found in oil polluted environment. Further research is suggested probably with a longer period of incubation, use of other species of mushroom or other petroleum products.

\section{Acknowledgements}

The author wishes to appreciate the immense contributions and constructive criticisms of Dr. Kolawole Falade and Prof. O. Akaranta.

\section{References}

[1] Kadafa, A.A. (2012) Oil Exploration and Spillage in the Niger Delta of Nigeria. Civil and Environmental Research, 2, 38-51.

[2] Gabriel, A.O.I. (2004) Women in the Niger Delta: Environmental Issues and Challenges in the Third Millennium. http://jsd-africa.com/Jsda/Fall2004/women\%20in\%20the\%20niger\%20delta.pdf

[3] Pirastu, R., Pasetto, R., Zona, A., Ancona, C., Iavarone, I., Martuzzi, M. and Comba, P. (2013) The Health Profile of 
Populations Living in Contaminated Sites: Sentieri Approach. Journal of Environmental and Public Health, 2013, Article ID: 939267. http://dx.doi.org/10.1155/2013/939267

[4] Wang, J., Jia, C.R., Wong C.K. and Wong, P.K. (2000) Characterization of Polycyclic Aromatic Hydrocarbon Created in Lubricating Oils. Water, Air and Soil Pollution, 120, 381-396. http://dx.doi.org/10.1023/A:1005251618062 http://link.springer.com/article/10.1023\%2FA\%3A1005251618062\#page-1

[5] Okonokhua, B.O., Ikhajiagbe, B., Anoliefo, G.O. and Emede, T.O. (2007) The Effects of Spent Engine Oil on Soil Properties and Growth of Maize (Zea Mays L.). Journal of Applied Sciences and Environmental Management, 11, 147-152.

[6] Field, C.B., Chapin, F.S., Matson, P.A. and Mooney, H.A. (1992) Responses of Terrestrial Ecosystems to the Changing Atmosphere: A Resource-Based Approach. Annual Review of Ecology and Systematics, 23, 201-235. http://dx.doi.org/10.1146/annurev.es.23.110192.001221

[7] Loske, D., Huttermann, A., Majcherczyk, A., Zadrazil, F., Lorsen, H. and Waldinger, P. (1990) Use of White-Rot Fungi for the Clean-Up of Contaminated Sites. Advances in Biological Treatment of Lignocellulosic Materials, Commission of the European Communities Making for the Remediation of Petroleum—Contaminated Sites. Land Quality Division, 22 September 2003.

[8] Adedokun, O.M. and Ataga A.E (2007) Effects of Amendments and Bio Augmentation of Soil Polluted with Crude Oil, Automotive Gasoline Oil, and Spent Engine Oil on the Growth of Cowpea (Vignaungiculata L. Walp). Scientific Research and Essay, 2, 147-149. http://www.academicjournals.org/journal/SRE/article-full-text-pdf/75F9B3D12559

[9] Adedokun, O.M. and Ataga, A.E. (2008) Degradation of Crude Oil by Pleurotus pulmonarius, Pleurotus tuber-regium and Lentinus squarrosulus. Proceedings of the 17th Congress of the International Society for Mushroom Science, Cape Town, 17, 824-832. http://www.pubhort.org/isms/

[10] Adenipekun, C.O. and Fasidi, I.O. (2005) Bioremediation of Oil Polluted Soil by Lentinus subnudus, a Nigerian White Rot Fungus. Africa Journal of Biotechnology, 4, 796-798. http://www.ajol.info/index.php/ajb/article/view/15184

[11] Wang, H.Z. and Ng, T.B. (2006) Purification of a Laccase from Fruiting Bodies of the Mushroom Pleurotus eryngii. Applied Microbiology and Biotechnology, 69, 521-525. http://dx.doi.org/10.1007/s00253-005-0086-7

[12] Ojumu, T.V., Bello, O.O., Sonibare, J.A. and Solomon, B.O. (2005) Evaluation of Microbial Systems for Bioremediation of Petroleum Refinery Effluents in Nigeria. African Journal of Biotechnology, 4, 31-35. http://www.ajol.info/index.php/ajb/article/view/15048

[13] USEPA (1998) Sonication Extraction Procedure-Method 3550. 3rd Edition, US EPA, Washington DC.

[14] Buswell, J.A., Cai, Y.J., Chang, S.T., Peberdy, J.F., Fu, S.Y. and Yu, H.-S. (1996) Lignocellulolytic Enzyme Profiles of Edible Mushroom Fungi. World Journal of Microbiology and Biotechnology, 12, 537-542. http://dx.doi.org/10.1007/BF00419469

[15] Stamets, P. (2005) Mycelia Running. How Mushrooms Can Help Save the World. Crown Publishing, New York, 343.

[16] Johannes, C., Majacherczyk, A. and Huttermann, A. (1996). Degradation of Anthracene by Laccase of Trametes versicolor in the Presence of Different Mediator Compounds. Applied Microbiology and Biotechnology, 46, 313-317. http://dx.doi.org/10.1007/s002530050823

[17] Bhatt, M., Cajthaml, T. and Šašek, V. (2002) Mycoremediation of PAH-Contaminated Soil. Folia microbiological, 47, 255-258. http://dx.doi.org/10.1007/BF02817647 http://link.springer.com/article/10.1007\%2FBF02817647

[18] Oregon Department of Environmental Quality (ODEQ) (2003) Risk-Based Decision making for the Remediation of Petroleum—Contaminated Sites. Land Quality Division, 22 September 2003.

[19] CCME (2010) Canadian Soil Quality Guidelines for Carcinogenic and Other Polycyclic Aromatic Hydrocarbons (PAHs) (Environmental and Human Health Effects). Scientific Criteria Document revised, Canadian Council of Ministers of the Environment, Gatineau, 216 p. 